\title{
Developments in rural areas in relation with developments in land and water management research in the Netherlands. 2. Rural development plans and research
}

\section{Bijkerk and C. G. J. van Oostrom}

Institute for Land and Water Management Research (ICW), Wageningen, Netherlands

Received 19 July 1982; accepted 17 August 1982

Key-words: land and water management, economic development, rural areas, production in agriculture.

\section{Summary}

The relationship between developments in type of improvement plans and scientific research is made clear. In the sphere of water management the basic research on geohydrology, drainage, evaporation and water supply is discussed as also the more recent water quality research, this being a factor of growing importance. Recent agricultural soil technology research also aims at applications in urban areas (sports fields and parks). The scope of land layout research widened from pure agricultural aspects to nonagrarian and multidisciplinary subjects of study (physical planning, traffic research, urbanization, outdoor recreation and multiple land use).

A general present aspect of water as well as land management research is the approach by means of regional studies, which also influences the fields of research. To keep up with the changing character of land improvement plans adaptations in basic and applied research are necessary.

\section{Main features of the development of land and water management research}

\section{Introduction}

In Part 1 of this study (Neth. J. agric. Sci. 31(1983)00-00) a sketch has been given of the agricultural economic development and its effect on land reconstruction measures in the Netherlands. In Part 2 it will be tried to give a general impression of the effect in the sphere of scientific and applied research.

Since 1955 a close relation exists between land consolidation practice and applied research through cooperation between a special department of the Governmental Service for Land and Water Use (850 employees, of which 120 in project research, and annual investments of Dutch guilders $\left.(f) 350 \times 10^{6}\right)$ and the Institute for Land and Water Management Research (ICW) (115 employees in basic research). The latter institute is one of the Government foundations for scientific and applied 
research, proceeding from the so-called 'Mansholt period'. For an extensive review of the research carried out by the ICW on land and water management research the book 'Research Digest 1980 ICW', which is available for free upon request, may be mentioned. This book has been published on the occasion of the 25 th anniversary of the Institute.

\section{Water management research}

In this section a short review will be given of the adaptation in research projects caused by the external developments.

Water management research comprises a number of technical problem fields such as:

- surface water (levels, open water courses) in connection with inundation and water supply;

- groundwater (drainage depth, drainage systems) in connection with crop yield;

- evaporation (sprinkling irrigation) in connection with crop yield;

- unsaturated flow in connection with crop yield and tillage practices.

This sequence expresses the increasing necessity for more intricate professional knowledge, caused by the development of increasing production and productivity in both agriculture and horticulture.

The economic evaluation of improvements in water management and soil became more feasible to apply as a consequence of an increasing knowledge of the underlying physical coherences.

The planning of water management projects resulted in a series of regional studies on geohydrology and regional water management (water supply in agriculture and horticulture, drinking water and process water for the industry). The regions concerned were: (1) the Delta area (province of Zeeland), (2) the Achterhoek (province of Gelderland), (3) Salland (province of Overijssel), the Mid-West Netherlands (province of Zuid-Holland) and the province of Noord-Holland.

Aspects of nature and landscape are becoming more and more important in water management projects at present. In that context knowledge concerning the relation between water management and ecosystems still is as yet a limiting factor in governmental policy. These aspects are now more and more integrated in the research programmes. The strong development of numerical models made the applicability for an adequate water management increase (water level control, water conservation, sprinkling irrigation, competition of water for agriculture and drinking water). In the late seventies, environmental aspects were coming more into the picture in land and water management projects. The rapidly increasing number of questions concerning the quality of groundwater and surface waters in The Netherlands led to the setting up of a separate department within the ICW in 1971. Subjects in the field of water quality now researched are:

- systems affecting the quality of groundwater and surface waters;

- relations between both agricultural and nonagricultural land use and water quality;

- land treatment of sewage water from agricultural industries on cultivated land;

- impact of land consolidation and other measures on the quality of groundwater 
and surface waters;

- water quality, reaction of plants and nature preservation.

\section{Soil technology}

Soil technological research finds its origin in the improvement of the soil profile aiming at an increase of production, such as subsoiling, oversanding, deep mixing, etc. Mechanization in agriculture is a closely related item through the problem of compacted soils.

Recent research projects are concerned with the consequences of various soil profile conditions for production and workability, with water management related to soil technology in particular regarding the unsaturated zone, and with the bearing capacity of soils. A central issue is the workability of the top soil in spring in connection with the spreading of labour over the season and the extension of the grazing and growing period.

Analysis of the processes of subsidence in low lying peat soils in polders, depending on the groundwater level is also considered to be an important subject of research. The fear of damage by subsidence to buildings, roads, etc. is dominant in decisions about a lowering of the water level in polders. The fundamental processes are now known, however, and exact estimates of the subsidence can be made.

The impact of non-agricultural aspects upon rural engineering is reflected in research on soil aeration of urban trees and on soil physical backgrounds of the layout and maintenance of sports fields.

\section{Land layout}

In comparison with the knowledge on land drainage and water management, research on land layout is of rather young date. This is illustrated by the spread of research capacity over the respective subjects. About twenty years ago, the research capacity of the ICW in this field was about $9 \%$ against $33 \%$ by now. The relatively rapid growth ( $7 \%$ per year in comparison to an annual $2.3 \%$ growth of the total capacity) reflects the urgent need of this type of knowledge for practical application.

The development of the rural area from a farmers domain to a multifunctional space has led within a relatively short period to a rapid broadening of the scope of research in rural engineering. It is a challenge to bring claims of an acceptable scientific level into perfect balance with the demand for practical research results, the more so as the number of disciplines in this kind of research rapidly increases.

Present fields of research can be indicated as follows:

- research on land layout (lots, parcels, roads, farms);

- development of a computerized inventory system on land use;

- research on resettlement of farmbuildings;

- optimizing of the allocation of new lots in reallocation projects;

- traffic research (types of traffic, origin-destination research, velocity research) with the aim of designing models for rural traffic, road maintenance, safety analysis;

- research on machine capacities in the execution of land consolidation projects 
(land levelling, ploughing, filling out ditches, and so on);

- research on private and regional economics with the aim to evaluate land consolidation projects;

- physical planning research focussed on the applicability of land allocation models in multiple land use plans;

- research on outdoor recreation: problems concerning location, capacity, layout and management of inland beaches, facilities in woods, sport fishery, pleasure driving, walking, picknicking, etc. Recently the periphery of towns with phenomena as dumping, uncertainties about destination and consequently a reluctance to invest demand much attention for purposes of buffer zoning, outdoor recreation, agriculture, afforestation, nature preservation and landscaping;

- housing in rural areas, analysis of strip villages, research on regional distribution of permanent (outdoor) recreation facilities;

- research on multiple land use, analytical research concerning several types of land use as well as natural and cultural resources, system analysis of plan generation, design criteria and evaluation of plans.

Presently a series of regional studies has been a (systematic) backbone of the research programmes. These regional studies deal or have dealt with:

- agricultural areas: Lollebeek (mixed farming), Veenkoloniën (arable farming) northern clay mosaic patterned areas (mixed farming);

- horticultural areas: Grootslag (bulbs), Rijsbergen-Zundert (market gardening), Westland (glasshouse horticulture);

- hedge landscapes in eastern sandy regions: Volthe-De Lutte (agriculture, nature preservation, landscape, outdoor recreation, forestry);

- grassland areas: Mid-West Netherlands, Lopikerwaard (agriculture, nature preservation, landscape, outdoor recreation, forestry, housing, traffic, water quality, soil, farm economy);

- wet land bird reserves: Eilandspolder (agriculture, water fowl, management regulations);

- sandy regions of Mid-Brabant: the triangle Eindhoven-Tilburg-'s Hertogenbosch (integral planning of agriculture, ecology, landscape).

From the third item onwards, the mentioned subjects of research have no longer been the exclusive domain of the ICW as they have been or are being studied in cooperation with other scientific research institutes. In the Mid-Brabant study for example, five institutes take part, viz the ICW, the Dorschkamp Research Institute for Forestry and Landscape Planning, the Research Institute for Nature Management (RIN), the Soil Survey Institute (Stiboka) and the Agricultural Economics Research Institute (LEI).

\section{Final remarks}

The purpose of this study was to show how scientific land and water management research in the Netherlands has constantly been focussed on future developments in rural engineering in accordance with the social development of the rural area. The experiences with multidisciplinary approaches should not be judged without 
some benevolence, since scientists with in principle antagonistic aims in rural planning are involved. It is to be hoped that design criteria for land use planning such as have recently been developed for experimental purposes may actually be accepted as applicable for the benefit of harmonious plans for the regions involved. 